\title{
Multiple Wh-Fronting in Serbo-Croatian Matrix Questions and the Matrix Sluicing Construction
}

\author{
Sandra Stjepanović \\ West Virginia University
}

\section{Introduction}

In this paper I examine two problems with respect to multiple Wh-fronting in Serbo-Croatian. One problem has to do with the positions to which Wh-phrases are moving and the driving force behind this movement. As is well-known, in the majority of cases, Wh-phrases in SC cannot stay in their in situ position, and have to be in some position preceding the verb, as illustrated in (1).
(1) a. *Ko kupuje šta gdje?
who buys what where
'Who buys what where?'
b. $\quad *$ Ko šta kupuje gdje?
c. Ko šta gdje kupuje?

Given this state of affairs, two question immediately arise: what exactly are the positions to which Wh-phrases are moving and what the driving force behind this movement is. Rudin (1988) argues that the Wh-phrase which is the first in the linear order moves to SpecCP, while others are adjoined to IP. The movement of the first Wh-phrase can be taken to be an instance of familiar Wh-movement to SpecCP for checking of a Wh-feature in C. As far as the second Wh-phrase is concerned, however, a question immediately arises as to what the driving force for the movement of this Wh-phrase is. This question becomes even more interesting in the light of Bošković's (1997b, 1998b) argument that in certain cases, even the first Wh-phrase does not move to SpecCP overtly, although it is fronted.

An attempt to find an answer to this question will reveal that there is a parallelism between Wh-phrases and identificationally focused material (in the sense of É. Kiss 1998) ${ }^{1}$ with respect to the positions they occupy in the sentence. It will be shown that identificationally focused material can undergo overt movement to certain syntactic positions, as illustrated in (2). ${ }^{2}$
(2) a. PETRA Marija voli.
Petar-ACC Marija-NOM loves
'Marija loves Petar.'
b. Marija PETRA voli.
'Marija loves Petar.'
Marija-NOM Petar-ACC loves 
In these sentences, the focused element is in an immediately preverbal or sentence initial position, it bears an emphatic stress and it is necessarily the only focus of the sentence.

I will first show that such sentences involve movement of identificationally focused elements to the projections where this focus is licensed. Then I will argue that multiple Whfronting is a sub-case of this focus movement. In this sense, SC offers support to the often noted observation that if a language marks focus syntactically (i.e. if the focused material has to occur in (a) particular position(s) in the sentence), these positions also host Wh-phrases. Some of the languages having this property are Somali, Chadic, Aghem, Basque, Hungarian, Omaha, Quetchua, Greek, and Finnish (see, among others, Horvath 1986, Rochemont 1986, and papers in É. Kiss 1995), and Romanian (Göbbel 1998).

The other problem I will be concerned with is the presence of Superiority effects in the sentences involving sluicing and multiple Wh-phrase remnants. I will call this type of sluicing multiple sluicing. It is a well-known fact about SC multiple Wh-fronting that it does not exhibit Superiority effects in short distance matrix questions (Rudin 1988, Bošković 1997b, 1998b), as (3) shows:

(3) a. Ko koga voli? who whom loves 'Who loves whom?'

b. Koga ko voli?

However, this freedom of Wh-phrase ordering is not manifested in the sentences such as (4b) and (4d), which involve multiple sluicing.

(4) a. Neko voli nekog. somebody loves somebody 'Somebody loves somebody.'

b. Ko koga? who whom 'Who (loves) whom?'

c. *Koga ko?

Examining the interaction between Superiority and multiple sluicing will reveal some interesting facts about this ellipsis phenomenon, and will shed more light on the nature of multiple Wh-phrase fronting.

\section{Multiple Wh-Fronting in SC}

Rudin (1988) shows that there are two types of multiple Wh-fronting languages. One type is the Bulgarian type, which includes languages such as Bulgarian and Romanian. Rudin argues that in this type of languages all fronted Wh-phrases are in SpecCP, forming a constituent, as in (5a). The other type of languages is the Serbo-Croatian type, which includes languages 
such as SC, Czech, and Polish. According to Rudin, in SC type of languages, the fronted Whphrases do not form a constituent; only the first Wh-phrase is located in SpecCP, while other fronted Wh-phrases are adjoined to IP, as shown in (5b).

$\begin{array}{ccc}\text { (5) a. } & {[\text { СP Koj kogo }[\text { IP vižda }]]} & \text { (Bulgarian) } \\ \text { who whom sees } & \\ \text { 'Who sees whom?' } & \text { (SC) } \\ \text { b. } \quad[\text { СР Ko }[\text { IP koga }[\text { vidi] }]] & \\ \text { who whom sees } & \\ \text { 'Who sees whom?' } & \end{array}$

One of Rudin's arguments for this conclusion concerns the fact that non-wh material cannot split fronted Wh-phrases in Bulgarian, while it can in SC, as shown in (6).

(6) a. Zavisi od tova, koj kogo přv e udaril. (Bulgarian) depends on it who whom first is hit 'It depends on who whom hits first.'

b. *Zavisi od tova, koj přv kogo e udaril.

c. Zavisi od toga ko koga prvi udari.

d. Zavisi odtogako prvikoga udari.

Another difference between the two types of languages observed by Rudin (1988) is that fronted Wh-phrases are subject to strict ordering constraints in Bulgarian type, but not in SC type, as illustrated in (7)

\begin{tabular}{|c|c|c|}
\hline a. & $\begin{array}{c}{[\text { се Koj kogo [vižda]] }} \\
\text { who whom sees }\end{array}$ & (Bulgarian) \\
\hline & 'Who sees whom?' & \\
\hline b. & *[CP Kogo koj [vižzda] $]$ & \\
\hline c. & $\begin{array}{c}{[\text { СP Ko [IP } k \text { koga }[\text { vidi]]] }} \\
\text { who } \quad \text { whom sees }\end{array}$ & (SC) \\
\hline d. & $\begin{array}{l}\text { 'Who sees whom?' } \\
\text { [CP Koga [IP ko [vidi]]] }\end{array}$ & \\
\hline
\end{tabular}

One question that immediately arises is why there are differences in constraints on linear ordering of Wh-phrases between Bulgarian and SC types. As for Bulgarian type, Rudin (1988) and Bošković (1997b, 1998b, 2002) argue that if adjunction to SpecCP in Bulgarian proceeds to the right, i.e. if the Wh-phrase that is first in the linear order is the one that moves first to SpecCP, the strict ordering of fronted Wh-phrases in Bulgarian follows from the Superiority Condition: the highest Wh-phrase has to move first; otherwise, there is a Superiority effect. As for SC type, Rudin concludes that Superiority does not hold in SC by looking only at the examples of the type in (7c-d), i.e. short distance null $\mathrm{C}$ matrix questions, and offers an analysis in which SC type languages never yield Superiority effects. However, 
Bošković (1997b, 1998b, 2002) shows that while it is true that in examples like (7c-d), SC does not show Superiority effects, in many other configurations Superiority effects do arise in SC. These configurations include embedded question contexts, long distance questions and matrix questions with overt $\mathrm{C}$, as shown in (8).

(8) Long-distance questions:

a. ?Ko si koga tvrdio da je istukao?

who are whom claim-2SG that is beaten

'Who do you claim that beat whom?'

b. ?*Koga si ko tvrdio da je istukao?

Embedded contexts: ${ }^{3}$

c. Ko koga voli, taj o njemu $i$ govori.

who whom loves that.one about him even talks

'Everyone talks about the person they love.'

d. ?*Koga ko voli, taj o njemu/o njemu taj $i$ govori.

e. Imako šta da ti proda.

has who what that you sells

'There is someone who can sell you something.'

f. *Ima šta ko da ti proda.

Root questions with overt C:

g. Ko li šta kupuje?

who C what buys

'Who on earth buys what?'

h. * * Šta li ko kupuje?

The ordering of fronted Wh-phrases in SC long-distance questions, embedded questions and matrix questions with overt complementizers is not free. In these contexts, the highest Whphrase has to appear first in the linear order, otherwise the sentence is bad, just as in Bulgarian. Bošković argues that if, like in Bulgarian, the Wh-phrase which is first in the linear order moves first, the ungrammaticality of $(8 \mathrm{~b}, \mathrm{~d}, \mathrm{f}, \mathrm{h})$ is due to a violation of the Superiority Condition. SC is then not exempt from the Superiority Condition. As Bošković points out, even if we did not have this empirical evidence, to claim that SC is exempt from the Superiority Condition would be conceptually problematic, since the Superiority Condition has recently been argued to follow from the Principles of Economy (Bošković 1997a, Cheng and Demirdache 1990, Kitahara 1997) which are presumably universal, and therefore not a plausible locus of cross-linguistic variation.

Superiority effects do not show up in SC short distance null C matrix questions (except in multiple sluicing contexts discussed below), while they do in a number of other contexts, including short distance overt $\mathrm{C}$ matrix questions, embedded contexts, and long-distance questions. Bošković (1997b, 1998b) offers an account of these facts. He bases his account on an interesting parallelism between SC and French. French exhibits the same division between different types of questions as $\mathrm{SC}$, but with respect to a somewhat different phenomenon. Exactly in those contexts in which SC exhibits Superiority effects, overt Wh-movement is 
obligatory in French, while in those contexts in which SC does not exhibit Superiority effects, overt Wh-movement does not need to take place in French (see Bošković 1997b for the relevant data in French). The curious behavior of SC with respect to Superiority can then be explained if one assumes that $\mathrm{SC}$ is a French-type language with respect to when it must have overt Wh-movement. Long-distance, embedded and overt $\mathrm{C}$ questions in SC then exhibit Superiority effects because in these contexts, overt Wh-movement must take place in $\mathrm{SC}$, just as in French. Short distance null C matrix questions in SC do not exhibit Superiority effects because, just like in French, these questions need not involve overt Wh-movement. As a result, Bošković argues, SC Wh-movement is well-behaved with respect to Superiority: Whenever there is overt Wh-movement in SC, Superiority is operative. The only difference between French and SC null C matrix questions is that in SC, Wh-phrases still must front for some reason that is independent of checking the $[+\mathrm{Wh}]$ feature of $\mathrm{C}$.

If there is overt movement of Wh-phrases, which is not driven by a $[+\mathrm{Wh}]$ feature of $\mathrm{C}$, the question is what it is driven by, and to what positions the phrases are actually moving. In the following sections I will show that Wh-phrases move to the same positions as phrases expressing identificational focus. In order to show this, I will first discuss sentences involving focus movement of non-wh elements.

\section{Focus Movement}

\subsection{Identificational vs. Information Focus}

In this section I will show that contrastively focused elements in SC undergo focus movement. First, let me discuss what I mean by contrastive focus. I will adopt É. Kiss's (1998) conception of contrastive focus, which is subsumed under the notion of identificational focus. É. Kiss (1998) argues that a distinction should be made between 'information' focus (sometimes also called presentational focus or new information focus) and identificational focus. She argues that these two types of focus have different syntactic and semantic properties. Identificational focus has the following semantic-communicative function:

(9) The function of identificational focus: An identificational focus represents a subset of the set of contextually or situationally given elements for which the predicate phrase can potentially hold; it is identified as the exhaustive subset of this set for which the predicate phrase actually holds.

(É. Kiss 1998:245)

According to É. Kiss (1998), semantically, the constituent expressing identificational focus represents the value of variable bound by an abstract operator expressing exhaustive identification. Syntactically, the constituent expressing identificational focus itself acts as an operator, moving into a scope position, the specifier of a functional projection, and binding a variable.

Identificational focus thus expresses exhaustive identification. Furthermore, it does not 
have to be present in every sentence, but if it is present, it can trigger syntactic reordering of elements in the sentence.

New information focus, on the other hand, merely conveys nonpresupposed information, without expressing exhaustive identification, it is present in every sentence, and does not trigger any syntactic reordering.

A difference between these two kinds of focus can be seen from their behavior in the test of exhaustive identification devised by Szabolcsi (1981). This test involves a pair of sentences in which the first sentence has a focus consisting of a coordinate DP, and the second sentence differs from the first one only in that one of the DPs in the coordinate phrase is dropped, as illustrated in (10)-(11) for Hungarian, from É. Kiss (1998):

(10) a. Mari EGY KALAPOT IS EGY KABÁTOT nézett ki magának.
Mary a hat-ACC and a coat-ACC picked out herself.to
'It was a hat and a coat that Mary picked for herself.'
Mari EGY KALAPOT nézett ki magának.
Mary a hat-ACC picked out herself.to
'It was a hat that Mary picked for herself.'
(11) a. Mari nézett ki magának EGY KALAPOT IS EGY KABÁTOT.
Mary picked out herself.to a hat-ACC and a coat-ACC
'Mary picked a hat and a coat for herself.'
Mari nézett ki magának EGY KALAPOT.
Mary picked out herself.to a hat-ACC
'Mary picked a hat for herself.'

The examples in (10) involve focused elements in a preverbal position, while the examples in (11) involve postverbal focus. As É. Kiss (1998) points out, if the second sentence is not among the logical consequences of the first one, the focus expresses exhaustive identification. While the Hungarian sentence in (11b) is among logical consequences of the sentence in (11a), the sentence in (10b) is not a logical consequence of the sentence in (10a), on the contrary it contradicts (10a). The sentence in (10b) passes this test of exhaustivity while the sentence in (11b) does not. The examples in (11) involve information focus, while the examples in (10) involve identificational focus. É. Kiss (1998) claims that English it-cleft sentences show the same behavior as Hungarian sentences in (10), as the translations of (10ab) show, which leads her to conclude that focus in these sentences is identificational focus. Identificational focus introduces an operator which changes the truth conditions of the sentence, which is not the case with information focus.

É. Kiss (1998) also points out that there are two versions of identificational focus. Identificational focus can express contrast, which is identification with exclusion, or identification only. According to É. Kiss (1998), identificational focus expresses contrast, if it operates on a closed set of entities whose members are known to the participants of the discourse. In this case, the identification of a subset of a given set also identifies the contrasting complementary subset. However, identificational focus can also operate on an 
open set of entities, as in the Hungarian example in (12b), which is an answer to the question in (12a), from É. Kiss (1998).

(12) a. Ki irta a Háború és békét? who wrote the War and Peace 'Who wrote War and Peace?'

b. A Háború és békét TOLSTSZTOJ irta. the War and Peace Tolstoy wrote 'It was Tolstoy who wrote War and Peace.'

(12b), as an answer to the question in (12a), does not presuppose a closed set of persons who might have written War and Peace. As a consequence, according to É. Kiss, the identification of the subset for which predicate holds does not result in the delineation of a complementary subset with clearly identifiable elements. In this case, identificational focus is not contrastive.

É. Kiss (1998) shows that in Hungarian, identificational focus is associated with the preverbal position, and that this focus movement of identificationally focused elements is obligatory in Hungarian. She also reports several other languages, in which identificational focus undergoes movement to a certain syntactic position, these languages being Romanian, as discussed in G'bell (1998), Italian, Greek, discussed in Tsimpli (1994), Arabic, as discussed in Ouhalla (1994) and Finnish, discussed in Vilkuna (1995). She shows that these languages might be parameterized with respect to whether this focus is [ \pm contrastive].

\subsection{Identificational Focus in SC}

In this section I will show that $\mathrm{SC}$ is also one of the languages that require elements expressing identificational focus to move to a particular position in the sentence.

In sentences such as those in (2) and repeated here as (13), focus expresses exhaustive identification. The interpretation of the sentence is such that Petar is the only one of a set of relevant persons that Marija loves.
(13) PETRA Marija voli.
Petar-ACC Marija-NOM loves
'It is Petar that Marija loves.'

We can confirm that focus in cases such as these expresses exhaustive identification by applying Szabolcsi's (1981) test illustrated in (10)-(11). Consider the pairs of SC sentences in (14) and (15).

(14) a. PETRA I IGORA Marija voli.

Petar-ACC and Igor-ACC Marija loves

'It is Petar and Igor that Marija loves.'

b. PETRA Marija voli.

Petar-ACC Marija loves 
'It is Petar that Marija loves.'

(15) a. Marija voli PETRA I IGORA.

Marija loves Petar-ACC and Igor-ACC

'Marija loves Petar and Igor.'

b. Marija voli PETRA.

Marija loves Petar-ACC

'Marija loves Petar.'

In (14), the sentence in (14b) is not among logical consequences of the sentence in (14a). In (15), on the other hand, the sentence in (15b) is among logical consequences of the sentence in (15a). This means that in sentences in (14), focus expresses exhaustive identification, which is not the case with sentences in (15).

A similar situation also obtains in the pair of sentences in (16), which differ from the sentences in (14) in that the focused element is located in an immediately preverbal position, instead of in the sentence initial position as in (14).

(16) a. Marija PETRA I IGORA voli.

Marija Petar-ACC and Igor-ACC loves

'It is Petar that Marija loves.'

b. Marija PETRA voli.

Marija Petar-ACC loves

'It is Petar that Marija loves.'

These sentences could be used in the same contexts as the sentences in (14). Just as in sentences in (14), in these cases too, the sentence in (16b) is not a logical consequence of the sentence in (16a), indicating that exhaustive identification is at play.

It is obvious that in the examples (14) and (16), the focused elements do not occupy their base-generated position, which is one following the verb. This raises the question of what positions they actually occupy and how they get in these positions.

There is evidence showing that the relevant positions are located above TP and between TP and VP. First of all, note that in sentences in (14), the focused element precedes the subject. In (16), however, it follows the subject. So, there must be two positions capable of hosting an identificationally focused element. Consider now the following data:

(17) a. Oni mudro JOVANA savjetuju.

they wisely Jovan-ACC advise

'It is wise of them to advise Jovan.'

'They advise Jovan in a wise manner.'

b. Oni JOVANA mudro savjetuju. they Jovan-ACC wisely advise

'*It is wise of them to advise Jovan.'

'They advise Jovan in a wise manner.' 


\section{JOVANA oni mudro savjetuju.}

Jovan-ACC they wisely advise

'It is wise of them to advise Jovan.'

'They advise Jovan in a wise manner.'

According to Jakendoff (1972) some adverbs, such as wisely, are ambiguous between a subject-oriented and manner reading. On the latter reading, the adverb is a VP adverb, while on the former, it has a sentential reading. The adverb mudro 'wisely' exhibits an interesting behavior in the sentences in (17)-(18). In (17a), where the adverb precedes the focused element, both the sentential and manner readings are available, as indicated by English translations of the sentence. In (17b), where the focused element follows the adverb, on the other hand, the only possible reading of the adverb is the manner reading. (18) shows that when the focused element is sentence initial, both readings are available. The question is how do we interpret these facts.

Stjepanović (1998) takes these facts to show that there are two focus positions where identificationally focused material is licensed, by adopting Bošković's (1997a) argument based on Watanabe (1993) that sentential adverbs are adjoined to TP, while VP adverbs are adjoined to VP. The contrast in the interpretation possibilities of adverbs in these two sentences shows that one focus position is below TP. In cases where the sentential reading of the adverb is available, it means that the adverb can be adjoined to TP, while in cases where it is not available, it means that the adverb cannot be adjoined to TP and has to be lower in the structure. Since in (17b), where the focused phrase precedes the adverb, the sentential reading of the adverb is not available, it means that the adverb cannot be adjoined to TP, and it means that the focused phrase must be adjoined lower than TP, too. If the adverb precedes the focused phrase, as in (17a), both sentential and manner readings are available. This means that the adverb could be adjoined either to VP or TP, which means that the focused phrase is at least as high as the VP adjoined position. Stjepanović (1998) takes the VP adjoined position to be one position where identificational focus is licensed. (18) shows that when a focused phrase is sentence initial, both readings of the adverb are available, which means that the focused phrase is higher than TP. Stjepanović (1998) takes this position to be AgrSP position. Bošković (1997b, 1998b) notes, however, that if one takes the lower focus position to be an AgrOP adjoined position (assuming that VP adverbs can also adjoin to AgrOP), then the job of focus licensing in SC can be reduced to a single category, AgrSP and AgrOP being the same category in two different positions. ${ }^{4}$

\subsection{Multiple Wh-Fronting: A Case of Focus Movement}

We have seen above that $\mathrm{SC}$ is a type of multiple Wh-fronting language in which the second phrase does not undergo overt Wh-movement to SpecCP, although it fronts overtly. We have also seen that based on certain facts about Superiority in SC, Bošković (1997b, 1998b) has argued that in null $\mathrm{C}$ short-distance matrix questions, even the first Wh-phrase need not move to SpecCP, although it fronts overtly. The question is where they move and why. 
Note now that positions in which Wh-phrases could be found are exactly those where identificationally focused elements are found, as illustrated in (19). ${ }^{5}$
(19) a. Ko mudro koga savjetuje?
who wisely whom advises
'?? Who is it wise of to advise whom?'
b. Ko koga mudro savjetuje?
who whom wisely advises
'*Who is it wise of to advise whom?'
'Who advises whom in a wise manner?'
c. Koga ko mudro savjetuje?
whom who wisely advises
'?? Who is it wise of to advise whom?'
'Who advises whom in a wise manner?

In (19), exactly the same judgments obtain with respect to the interpretation of the adverb mudro 'wisely', as in the examples involving focused phrases. This means that Wh-phrases could be occupying the same positions that identificationally focused phrases do. This is not implausible. Cross-linguistically it is well attested that interrogative Wh-phrases share the syntactic behavior of focused phrases. In languages in which focus phrases move to a certain position, Wh-phrases also move there. As shown in a number of articles in É. Kiss (1995), these languages are typologically as different as Somali, Chadic, Basque, Aghem, Hungarian, Haida, Omaha, Quetchua, Korean, Greek or Finnish. Stepanov (1998) argues that a similar situation obtains in Russian. Kidwai (1999) claims that the same situation holds in HindiUrdu. (20)-(21) shows examples from Hungarian and Aghem from Horvath (1986), which are all languages where focused and Wh-phrases occupy the same syntactic positions.

(20) a. Attila melyik lanyt szereti legjobban?

Attila which girl-ACC likes best

'Which girl does Attila like best?'

b. *Attila szereti legjobban melyik lanyt.

c. Attila A FOLDRENGESTOL felt.

Attila the earthquake.from feared

'Attila was afraid of the earthquake.'

d. *Attila felt A FOLDRENGESTOL.

(21) a. a mo nin ndugho

DS P2 run who

'Who ran?'

b. *ndugho mo nin (no)

who P2 run FOC

'Who ran?'

c. fil a mo zi ANSOM be-ko 

friends SMP2 eat in farm fufu
'Friends eat fufu in the farm.'
d. *fil a mozi be-ko ANSOM.

The overwhelming cross-linguistic evidence in this respect has led Horvath (1986) to express this Wh-phrase - focus phrase connection in a form of a universal principle, given in (22).

(22) The syntactic position(s) in which non-echo interrogative Wh-phrases can appear in a language $\mathrm{L}$ will be identical to or be a proper subset of the position in which Focus constituents can appear in the language L.

The correspondence between Focus movement and the overt movement of Wh-phrases leads Horvath to conclude that Wh-phrases are inherently focused. A similar conclusion was reached by Rochemont (1986). If this is true, then we can assume that Wh-phrases necessarily have a focus feature which is licensed in the positions in which non-wh focused phrases are licensed.

To sum up, I have shown that identificational focus is licensed in particular syntactic positions in SC. These positions also host Wh-phrases in SC, which suggests that the driving force behind multiple Wh-fronting and identificational focus fronting is the same.

\section{Multiple Sluicing and Superiority}

We have seen that in SC, Wh-phrases have to be fronted, but their fronting need not be due to checking of a [+Wh] feature in C. In original Rudin's (1988) analysis, this was the case with the second Wh-phrase. In Bošković's (1997b, 1998a, 1998b, 2002) analysis based on the ambivalent behavior of Superiority, in those cases which should be Superiority violations, but they are not, none of the Wh-phrases is undergoing overt Wh-movement to SpecCP. According to Bošković, their overt fronting is due to some other reasons. In the preceding sections, I have shown that this non-Wh-movement overt fronting of Wh-phrases is due to focusing reasons. Bošković takes this proposal and builds it into his analysis of the presence and absence of Superiority in SC. According to Bošković, if Wh-phrases are undergoing only focus movement, then no Superiority effects are detected. In his system then, focus movement is not subject to Superiority. As it will be seen below, the lack of Superiority effects with focus movement is derived from Economy of Derivation due to formal properties of focus movement.

At this point I would like to add another context in which Superiority effects seem to show up in SC, which is found in the examples in (23). This context is interesting, because it involves short distance null $\mathrm{C}$ matrix questions, which is exactly the context in which Superiority effects should not show up. However, as we can see in (23), movement of originally lower Wh-phrase across a higher one results in degradation, suggesting that Superiority is at play. It would be interesting then to see why such examples as (23) exhibit 
restrictions on ordering of Wh-phrases.

(23) A: Neko je udario nekog.

somebody is hit someone

'Somebody hit someone.'

B: Ko koga?

who whom

'Who hit whom?'

B: ?*Koga ko?

whom who

'Who hit whom?'

I will argue that this context involves sluicing with multiple remnants, or multiple sluicing. Examining the interactions between Superiority and multiple sluicing will reveal some interesting facts about what component of grammar this ellipsis phenomenon takes place in, and will shed more light on the nature of Wh-phrase focus fronting.

\subsection{Multiple Sluicing in SC}

Consider the following SC sentences.

(24) A: Neko je nekad ovdje sakrio blago.

somebody is somewhere here hidden treasure

'Somebody hid the treasure here at some point in the past.'

B: Ko kad?

who when

'Who (hid the treasure) when?'

B: $\quad$ ?*Kad ko?

(25) A: Neko jenegdje sakrio blago.

somebody is somewhere hidden treasure

'Somebody hid the treasure somewhere.'

B: Ko gdje?

who where

'Who (hid the treasure) where?'

B: $\quad$ ?*Gje ko?

(26) A: Neko je nekoga sakrio ovdje.

somebody is somebody hid here

'Somebody hid somebody here.'

B: Ko koga?

who whom

'Who (hid) whom (here)?' 


\section{B: $\quad ? * K o g a k o ?$}

The Speaker B utterances in (24)-(26) are multiple matrix questions with a null C. All of them contain only Wh-words, with the rest of the sentence material elided by some sort of ellipsis. On the face of it, the ellipsis process can be either gapping or multiple sluicing, which has been argued to exist, among others, in Japanese (Takahashi 1994), Korean (Kim 1998), and to some extent in English (Bolinger 1978, Merchant 1999, Richards 1997). I will show here that the ellipsis process in these examples is sluicing rather than gapping.

Jackendoff (1971) and Takahashi (1994) point out that gapping in English is unacceptable with conjuncts other than and:

(27) *Bill ate the peaches, but Harry the grapes.

The conjunction in (27) is but, and the sentence is degraded. SC also has a restriction on what conjunction can appear in unambiguously gapping constructions. The conjunction has to be $a$, the counterpart of English and. With ali 'but' the sentence is bad, as illustrated in (28).

(28) a. Ivan je pojeo jabuku, a Petar breskvu.

Ivan is eaten apple, and Petar peach

'Ivan ate an apple, and Petar a peach.'

b. *Ivan je pojeo jabuku, ali Petar breskvu.

Ivan is eaten apple, but Petar peach

'Ivan ate an apple, but Petar a peach.'

Sluicing is possible with ali 'but', as illustrated in (29).

(29) Ivan je vidio nekoga, ali ne znam koga.

Ivan is seen somebody but not know whom

'Ivan saw somebody, but I don't know whom.'

It is also possible to construct a parallel example to (29) with multiple remnants. Ali 'but' is still possible:

(30) Neko je vidio nekog, ali ne znam ko koga. somebody is seen somebody but not know who whom 'Somebody saw someone, but I don't know who whom.'

The example in (30) then seems to be an instance of multiple embedded sluicing and not gapping. In fact, embedded gapping is unacceptable (Lasnik and Saito 1992), while such sluicing is perfect, as illustrated in (31a) for gapping and in (31b) for sluicing.

(31) a. *John likes Mary, and I think that Bill Jennifer, too. 
b. John likes somebody, but I don't know who.

The same situation obtains in Serbo-Croatian. Gapping with subordination is not possible:

(32) *Ivan je volio Mariju, a mislim da Goran Vesnu.

Ivan is loved Marija, and think that Goran Vesna

'Ivan loved Marija, and I think that Goran loved Vesna.'

Sluicing with subordination, on the other hand is possible, as illustrated in (29). Furthermore, the example in (30) with multiple remnants is perfect, just like the sluicing example in (29) and unlike the gapping example in (32). Thus, the process of eliding all the sentence material except Wh-phrases in (30) is not gapping.

Lasnik (1999) shows that matrix sluicing is possible in English.

(33) A: Mary loves somebody?

B: Who?

Just as in English, sluicing is also allowed in matrix contexts in SC:

(34) A: Marija je voljela nekog.

Marija is loved somebody

'Marija loved somebody.'

B: Koga?

whom

'Whom?'

If it is possible to have embedded sluicing with multiple remnants, then one would expect it to be possible to have matrix sluicing with multiple remnants. The Speaker B utterances in (24)-(26) seem to be exactly examples of sluicing with multiple remnants.

Furthermore, as pointed out by Ross (1969), in single remnant sluicing, the remnant Wh-phrase in the sluiced conjunct usually corresponds to an indefinite DP in the antecedent conjunct as in (31b), but it does not have to, for example, it does not correspond to anything visible on the surface in (35).

(35) He is writing, but I don't know what.

The same situation obtains with multiple remnants in SC: neither in embedded nor in matrix clauses do they need to have corresponding indefinite phrases in the antecedent.

(36) a. Marko piše, ali ne znam šta kome.

Marko writes but not know what whom

'Marko is writing, but I don't know what he is writing to whom.'

A: Marko piše.

Marko writes 

'Marko is writing.'
B: $\quad$ Sta kome?
what whom
'What (is he writing) whom?'

With gapping, the antecedents of remnants must be present overtly, as illustrated in (37).

(37) a. Marko piše pismo, a Petar pjesmu

Marko writes letter-ACC and Petar poem-ACC

'Marko is writing a letter, and Petar a song.'

b. *Marko piše, a Petar pjesmu

Marko writes and Petar poem-ACC

'Marko is writing, and Petar a song.'

Given these facts, I conclude that examples in (24)-(26) are instances of multiple matrix sluicing, and not gapping.

One curious thing about the multiple sluicing examples in (24)-(26) is that they exhibit strict ordering of Wh-phrases. If the higher Wh-phrase appears first, the sentence is good, as in (24a)-(26 a), but if the lower Wh-phrase appears first, the sentence is bad, as in (24b)(26b). This is curious because if the Speaker B responds with full sentences without ellipsis, there are no constraints on linear ordering of Wh-phrases, as shown in (38)-(40). ${ }^{6}$

(38) A: Neko je nekad ovdje sakrio blago.

somebody is some.time.ago here hidden treasure

'Somebody hid the treasure here at some point in the past.'

B: Ko je kad ovdje sakrio blago?

who is when here hidden treasure

'Who hid the treasure here when?

B: Kad je ko ovdje sakrio blago?

(39) A: Neko jenegdje sakrio blago. somebody is somewhere hidden treasure 'Somebody hid the treasure somewhere.'

B: Ko je gdje sakrio blago? who is where hidden treasure 'Who hid the treasure where?'

B: Gdje je ko sakrio blago?

(40) A: Neko je nekoga ovdjesakrio. somebody is somebody here hidden 'Somebody hid somebody here.'

B: Ko je koga ovdje sakrio? who is whom here hidden 


\section{'Who hid whom here?' \\ B: Koga je ko ovdje sakrio?}

The constraint on linear ordering of Wh-phrases in examples (24)-(26) is reminiscent of the Superiority Condition. If the linear ordering of the Wh-phrases in these examples is constrained by some version of Superiority, then the question is why Superiority effects emerge in these matrix null $\mathrm{C}$ questions, when they do not normally do in other null $\mathrm{C}$ matrix questions. In order to give an answer to this question, I first have to examine current analyses of Superiority with multiple Wh-fronting.

\subsection{Superiority in $S C$}

The question is what is responsible for this ambivalent behavior of $\mathrm{SC}$ with respect to Superiority. There are at least two recent analyses in the literature attempting to offer an answer to this question. One of them is Bošković (1997b, 1998a, 1998b), which has partially been given above, and the other is Richards (1997).

As mentioned above, Bošković draws a parallel between French and $\mathrm{SC}$ with respect to the contexts in which Wh-movement takes place in these languages. This leads him to a conclusion that the curious behavior of SC with respect to Superiority can be explained if one assumes that SC is a French-type language with respect to when it must have overt Whmovement. Overt Wh-movement is present in long-distance, embedded and overt $\mathrm{C}$ questions in SC just as in French. Short distance null $\mathrm{C}$ matrix questions in SC just need not involve overt Wh-movement, just as in French. Wh-phrases still front, though. On the question of motivation for this fronting in null C matrix question, Bošković follows Stjepanović (1998), who shows that in these questions Wh-phrases appear in the positions in which contrastively focused material occurs. Fronted Wh-phrases that do not end up in SpecCP then undergo focus movement. The question that arises at this point is why Wh-movement is obligatory in French and $\mathrm{SC}$ embedded, long distance and overt $\mathrm{C}$ matrix questions, unlike in null $\mathrm{C}$ matrix questions. Bošković argues that a possible answer to this question lies in lexical insertion possibilities provided by the current minimalist framework (Chomsky 1995), and Chomsky's (1995) definition of strong features. Bošković argues that lexical insertion, or, more precisely Merger, can occur in LF under well-defined conditions: the element to be merged must be phonologically null since LF cannot deal with phonological features, and Merger must be at the top of the tree, since, by definition, Merger must expand the structure. Even an element with a strong feature can be inserted in LF, given Chomsky's (1995) definition of strong features, where strong features are defined derivationally as objects that cannot be tolerated by the derivation and need to be eliminated immediately upon their introduction into the structure. So, according to Bošković, French and SC do not have obligatory overt Whmovement in null $\mathrm{C}$ matrix questions because a null $\mathrm{C}$ with a strong Wh-feature, the trigger for Wh-movement, can be inserted in LF here. In embedded, long distance and overt C matrix questions, LF C insertion is blocked (see Bošković 1997b for discussion). C has to be present in the overt syntax, hence overt Wh-movement is obligatory in this case. As a result, in such multiple questions Superiority effects show up if the Wh-feature is not checked in the 
most economical way, given the Economy account of Superiority adopted by Bošković. The most economical way to check the $[+\mathrm{Wh}]$ feature is through the shortest movement possible, i.e. by moving the Wh-phrase that is closest to C. The movement of a Wh-phrase to SpecCP triggers Spec-head agreement with $\mathrm{C}$, checking the Wh-feature, so that the Wh-phrase that moves there first necessarily checks it. In Bošković's theory, overt Wh-movement to SpecCP triggers Superiority effects, while focus movement does not. Bošković argues that focus movement does not violate Superiority if (a) the focus feature attracting focus and Whelements is an Attract All feature attracting all focus elements, and (b) the Economy account of Superiority is adopted, whereby every feature has to be checked in the most economical way, i.e. through the shortest movement possible. Consider how his system works. ${ }^{7}$

(41) Wh-movement

$\begin{array}{llll}\text { F } & \text { Wh-phrase }_{1} & \text { Wh-phrase } & \text { Wh-phrase } \\ + \text { Wh } & + \text { Wh } & + \text { Wh } & + \text { Wh } \\ \text { strong } & \text { weak } & \text { weak } & \text { weak }\end{array}$

So, according to Bošković (1999), with Wh-movement, the attractor is an Attract 1F(eature). This means that it attracts only one feature, which has to be checked in the most economical way, i.e. through the shortest movement possible. Here, the situation is the same as in languages like English, where the attractor for Wh-movement $([+\mathrm{Wh}] \mathrm{C})$ is clearly an Attract $1 \mathrm{~F}$ head. Hence, if Wh-phrase ${ }_{1}$ does not move first to check it, a Superiority effect will result. With focus movement, the Focus attractor is an Attract All feature. Since it is an Attract All feature, it attracts all focus feature bearing elements. As a result, no Superiority effects will be expected with Focus movement. The Attract All property is satisfied in the same way from the point of view of economy regardless of the order in which the Wh-phrases move to the focused head. In (42), regardless, whether the Wh-phrases move in 1-2-3, 1-3-2, 2-1-3, 2-3-1, $3-1-2$, or 3-2-1 order, the same number of nodes will be crossed to satisfy the Attract All feature of the relevant head. Hence, the lack of Superiority with focus movement.

(42) Focus movement

$\begin{array}{llll}\text { F } & \text { Wh-phrase }_{1} & \text { Wh-phrase }_{2} & \text { Wh-phrase } \\ \text { +Focus } & \text { +Focus } & \text { +Focus } & \text { +Focus } \\ \text { strong } & \text { weak } & \text { weak } & \text { weak }\end{array}$

So, for Bošković, the ambivalent behavior of SC with respect to Superiority is a result of the interaction of several aspects of grammar, including the Economy account of Superiority, lexical insertion possibilities and the nature of strong features.

As far as Bulgarian type languages are concerned, which exhibit Superiority effects in all contexts, Bošković argues that this is so because in these languages, $\mathrm{C}$ is lexically specified as a phonological affix, and it therefore must be inserted in the overt syntax. Recall that LF insertion of elements which are not phonologically null is not possible, since LF cannot deal with phonological information. So, a Wh-phrase in Bulgarian always undergoes overt movement to SpecCP to check a strong Wh-feature. Given the Economy account of 
Superiority, this will be the highest Wh-phrase. As discussed above, however, Rudin (1988) shows that in Bulgarian multiple questions all Wh-phrases are in SpecCP, not just the highest one. The question is why other phrases also move to SpecCP. Bošković argues that the answer to this question lies in focus movement. Just like in $\mathrm{SC}$, all Wh-phrases in Bulgarian must undergo focus movement. The focus licenser in Bulgarian is C. So, the highest Whphrase has to move first in order to satisfy the strong Wh-feature of $\mathrm{C}$, at the same time checking its own focus feature. Other Wh-phrases are attracted by the Attract All focus, and thus just as in SC, it does not trigger Superiority effects. As a result, in Bulgarian, the highest Wh-phrase has to move first, and after that the order of movement of Wh-phrases is free, as shown in (44). (43) shows that when only two phrases are present, if kak is the first in the linear order and kogo follows, Superiority effects arise. In (44), however, as long as the highest subject moves first, there are no ordering requirements on kak and kogo.

(43)
a. Kogo kak e tselunal?
who how is kissed
'Who did he kiss how?' how whom is kissed
'Who did he kiss how?'
b. *Kak kogo e tselunal?

(44) a.
Koj kogo kak e tselunal?
who whom how is kissed
'Who kissed whom how?'
b. Koj kak kogo e tselunal?
who how whom is kissed
'Who kissed whom how?'
c. *Kogo kak koj e tselunal?
whom how who is kissed
'Who kissed whom how?'

As mentioned above, an alternative analysis of the different behavior of SC and Bulgarian with respect to Superiority and the ambivalent behavior of SC in this respect is offered by Richards (1997). For Richards (1997), the difference between SC and Bulgarian with respect to Superiority lies in the interaction of several aspects of grammar, in particular the Principle of Minimal Compliance in (45), and a constraint on Attract, given in (46). The definition of Attract is given in (47).

(45) Principle of Minimal Compliance (PMC)

For any dependency $\mathrm{D}$ that obeys constraint $\mathrm{C}$, any elements that are relevant for determining whether $\mathrm{D}$ obeys $\mathrm{C}$ can be ignored for the rest of the derivation for purposes of determining whether any other dependency D' obeys C.

(46) $\underline{\text { Shortest }}$ 
A pair P of elements $\{\square, \square\}$ obeys Shortest iff there is no well-formed pair P' which can be created by substituting $\square$ for either $\square$ or $\square$, and the set of nodes ccommanded by one element of $\mathrm{P}^{\prime}$ ' and dominating the other is smaller than the set of nodes c-commanded by one element of $\mathrm{P}$ and dominating the other.

(47) Attract

An attractor $\mathrm{K}$ attracts a feature $\mathrm{F}$, creating a copy $\square$ ' of an element $\square$ containing F, and Merging $\square$ ' with $\mathrm{K}$. The relations between $\square$ ', $\mathrm{K}$, and $\mathrm{F}$ must all obey Shortest.

Shortest constrains the relation between the attractor $\mathrm{K}$ and the attracted feature $\mathrm{F}$, forcing the attractor to attract the nearest possible feature. This is what Richards calls Shortest Attract. Shortest also constrains the relation between $\mathrm{F}$ and the copy $\square$ ' of $\square$, requiring that movement be as short as possible. In this way, Shortest prevents movement of F past an attractor which could attract $\mathrm{F}$, and also forces movement to be to the closest available landing site. This is what Richards calls Shortest Move. Richards argues that the interaction between PMC and Shortest, as well as the assumption that fronted Wh-phrases occupy multiple specifiers of C, can account for the Superiority effects in Bulgarian. In the case of multiple Wh-phrases, given Shortest, $\mathrm{C}$ first attracts the highest Wh-phrase. At this point PMC renders the attractor $\mathrm{C}$ immune to Shortest, i.e. it turns off Shortest Attract. As a result, $\mathrm{C}$ can attract the leftover Wh-phrases in any order. Furthermore, Richards argues that in the case of movement to multiple specifiers, an inner specifier is closer than an outer specifier. He also argues that although Shortest Attract is, Shortest Move is not affected by PMC. As a result, every subsequent movement of Wh-phrases will be to an inner specifier. This is what Richards calls "tucking in." So, in the case of Wh-phrases in (48), C first attracts Wh1 and PMC turns of Shortest Attract. As a result, $\mathrm{C}$ can attract either Wh2 or Wh3. If at this point it attracts Wh2, Wh2 will move and tuck in, i.e. it will move to a lower specifier of $C$. Then Wh3 tucks into the lowest specifier of $\mathrm{C}$. The resulting structure is given in (49). If, on the other hand, after attracting Wh1 first, $\mathrm{C}$ attracts Wh3 next, Wh3 will tuck into the lower specifier. After this C attracts Wh2, which moves to the lowest specifier. The resulting structure is given in (50).

C Wh1 Wh2 Wh3

[Wh1 [Wh2 [Wh3 [C]]]]

[Wh1 [Wh3 [Wh2 [C]]]]

As illustrated in (44), this is exactly the range of facts observed in Bulgarian. Richards' analysis thus works well for Bulgarian. As we have seen above, SC exhibits different behavior with respect to Superiority than Bulgarian. Unlike Bulgarian, SC lacks Superiority effects in short distance null $\mathrm{C}$ matrix questions, while in all other contexts it exhibits Superiority effects just like Bulgarian. Now, in order to explain why Superiority effects do not show up in SC short distance null C matrix questions, Richards argues that SC has a way 
of moving Wh-phrases other than Wh-movement to SpecCP. Local movement of Wh-phrases is A-scrambling. In particular, Richards argues that SC allows arbitrarily many attractors within IP projections, which are responsible for scrambling Wh-phrases. So, in case of two Wh-phrases, as in (51), one possible derivation is when there are two such attractors ( $\mathrm{X}$ and $\mathrm{Y}$ in (51)). The lower attractor $\mathrm{Y}$ attracts the higher Wh1. Now the higher attractor $\mathrm{X}$ must attract a Wh-phrase and the only Wh-phrase it can attract is the lower Wh2.

\section{(51) $\left.\left[\begin{array}{ll}\mathrm{CP} & \mathrm{C} \\ {[\mathrm{XP}} & \mathrm{X}\end{array}\left[\begin{array}{llll}\mathrm{yp} & \mathrm{Y} & {[\mathrm{Wh} 1} & \mathrm{Wh} 2\end{array}\right]\right]\right]$}

At this point $\mathrm{C}$ attracts Wh2, since it is the closest Wh-phrase. This derivation, therefore, yields a sentence in which the originally lower Wh-phrase moves to SpecCP without causing a Superiority effect, as in (7d). Given this mechanism, it is easy to think of a derivation where originally higher Wh-phrase ends up in SpecCP, an expected result, as in (7c).

Thus, in Richards' theory, an escape hatch from Superiority in these examples is Ascrambling. In long distance questions, however, Richards argues that this escape hatch is not available, and that this is why multiple long-distance Wh-fronting exhibits Superiority effects, as in (8b).

Having outlined these analyses of Superiority with multiple fronting, let us go back to the SC examples in (24)-(26). One prediction of Bošković's analysis is that if in SC null C multiple matrix questions, which do not normally exhibit Superiority effects, a null $\mathrm{C}$ can be forced to be present overtly, the Bulgarian pattern should emerge, i.e. a Superiority effect should show up. I will show that this is true of the data in (24)-(26). Under Richard's analysis, if all Wh-phrases are required to 'tuck in' the same specifier, Superiority effects should emerge even in SC, unless they are A-scrambled first.

\subsection{Multiple Sluicing and Superiority: Sluicing as PF Deletion}

Recall that I have argued that the data in (24)-(26) are instances of multiple sluicing. Sluicing with a single remnant is standardly analyzed as Wh-movement followed by IP deletion (Ross 1969, Rosen 1976, Takahashi 1994, Lasnik 1999, Merchant 1999), or base-generated null IP licensed by a [+Wh] C agreeing with its specifier and filled with linguistic material by LF copying (Levin 1982, Chung, Ladusaw and McCloskey 1995, among others). So, both types of accounts agree that the remnant Wh-phrase is in SpecCP. As far as multiple sluicing is concerned, there are analyses in which multiple remnants are also placed in SpecCP, such as Takahashi (1994). If we combine the proposal that Wh-phrases in sluicing examples are in SpecCP with Bošković's and Richard's analysis of the ambivalent behavior of SC with respect to Superiority, then Superiority effects in multiple matrix sluicing do not come as a surprise.

Recall that Bošković (1997b, 1998a, 1998b) argues that the ambivalent behavior of SC with respect to Superiority effects is caused by the absence or presence of $\mathrm{C}$ in overt syntax. If $\mathrm{C}$ has to be present in overt syntax, Superiority effects show up (embedded, long-distance and overt $\mathrm{C}$ contexts). If it does not need to be present in overt syntax, i.e. if it can be inserted in LF (null C in matrix questions), no Superiority effects show up. Now, if Wh-phrases in 
sentences undergoing sluicing are in $\mathrm{SpecCP}$, then $\mathrm{C}$ must also be present in overt syntax in such sentences. The strong Wh-feature it carries has to be eliminated in the most economical way. The most economical way is for it to be checked by the highest Wh-phrase. This means that the highest Wh-phrase has to move first. As far as the movement of the lower Wh-phrase is concerned, recall that Bošković claims that all Wh-phrases in SC are attracted by a strong focus feature with Attract All property. Furthermore, Bošković (1997b) shows that in the case of overt insertion of $\mathrm{C}$ in short distance matrix questions, $\mathrm{C}$ can act as a focus licensor for Wh-phrases in SC. Given this, it is not implausible to claim that the lower Wh-phrase in these examples moves to SpecCP to check its focus feature. This yields exactly the Bulgarian pattern discussed above.

Under Richard's analysis, since both Wh-phrases are moving to the same specifier, on the face of it, they should be strictly ordered. Recall that in his system, when phrases are moving to the same specifier, the highest one moves first, and then the lower one 'tucks' in the specifier below the one where the highest phrase has moved. One caveat with Richard's analysis, however, is the mechanism of arbitrarily many attractors in IP that is used to avoid Superiority effects in SC short distance matrix questions. As shown above, this mechanism of arbitrarily many attractors is able to scramble Wh-phrases rendering their order opposite of the original order. $\mathrm{C}$ then attracts the closest Wh-phrase, which due to scrambling may be the originally lower Wh-phrase. Superiority effects are then voided. Notice now that in the sluicing examples in (24)-(26), which are short distance questions, the escape hatch from Superiority in the form of arbitrarily many attractors in IP projections is still available. Given this mechanism, nothing prevents these phrases from being first scrambled and then attracted by $\mathrm{C}$ with the subsequent deletion of IP. As a result, Superiority effects should not show up, counter to fact. So, if the analysis of multiple sluicing I have presented here is right, these data would argue against such a mechanism.

Note now that given the Economy of Derivation account of Superiority, which Bošković (1998a) argues is superior to alternative accounts based on multiple Wh-fronting construction, and given SC data in (24)-(26), any account of sluicing as base-generated IP licensed by a [+Wh] C agreeing with the Wh-phrases in its specifier (possibly followed by LF copying) cannot be maintained. Under this approach, Wh-phrases are also base-generated in SpecCP, so any phrase could be base-generated first, checking the Wh-feature of C. Superiority effects then should not show up. If Wh-phrases, however, have to undergo overt movement, as in the Wh-movement and PF deletion of IP approach, then Superiority effects are expected to emerge in case the highest Wh-phrase does not move first to check the Whfeature.

So far I have examined the behavior of SC multiple matrix sluicing with respect to only two remnant Wh-phrases. I have shown that SC exhibits the Bulgarian pattern in this context with respect to Superiority. If SC follows the Bulgarian pattern in multiple matrix sluicing cases, then it should also behave like Bulgarian when more than two Wh-phrases are involved. As shown in (44), if there are more than two Wh-phrases in Bulgarian, Superiority cares only about the highest one, while it disregards other Wh-phrases in the sentence. So, in a sentence with three Wh-phrases, the highest Wh-phrase must move first, and then the order of movement of the other two Wh-phrases is free. As expected, SC behaves like Bulgarian in 
this respect:

(52) a. Ivanjenekog nekako prevario.

Ivan is someone somehow cheated

'Ivan cheated someone somehow.

b. Koga kako?

whom how

'How (did Ivan cheat) whom?'

c. ?*Kako koga?

how whom

d. Neko je nekog nekako prevario.

somebody is someone somehow cheated

'Somebody cheated someone somehow.'

e. Ko koga kako?

who whom how

'How (did) who (cheat) whom?'

f. Ko kako koga?

g. *Kako ko koga?

h. *Koga ko kako?

The contrast between (52b) and (52c) shows that prior to movement to SpecCP, kako 'how' starts lower in the structure than koga 'whom' (see Bošković 1997d for an explanation). The acceptability of (52e) and (52f) shows that if the highest Wh-phrase moves first, the order of other Wh-phrases is free, while $(52 \mathrm{~g})$ and $(52 \mathrm{~h})$ show that we get unacceptable constructions if the highest Wh-phrase does not move first.

The interaction of multiple sluicing and Superiority in SC thus argues against the null IP and Wh-phrase base-generation approach to sluicing, while they argue for the Whmovement followed by PF deletion approach to sluicing. Given that sluicing is an ellipsis phenomenon, then we have here an argument that ellipsis should be analyzed as a PF phenomenon.

\section{Conclusion}

The examination of the syntax of multiple Wh-fronting has shown that multiple Wh-fronting, when it does not involve movement for checking of a $[+\mathrm{Wh}]$ feature in $\mathrm{C}$, shares the syntactic behavior of identificational focus phrases. Multiple Wh-fronting is then decomposable in a familiar movement for checking of a Wh-feature in $\mathrm{C}$ and focus movement. Furthermore, the behavior of multiple Wh-phrases with respect to Superiority in sluicing constructions has revealed that sluicing must be a PF phenomenon. 


\section{Notes}

1. As will be discussed below, identificational focus is focus that expresses exhaustive identification and it subsumes contrastive focus.

2. Throughout the paper, identificationally focused material will be represented in capital letters and bold, while non-identificationally focused material will be represented in capital letters only.

3. Bošković (1997b, 1998b) avoids giving indirect questions as examples of embedded questions because such questions involve an interfering factor. As Bošković notes, indirect questions formally do not differ at all from matrix questions in SC. As a result, there is always a danger that they might be analyzed as matrix questions, with the superficial matrix clause treated as an adsentential. Instead, Bošković gives examples of correlative and existential constructions which, as shown by Izvorski (1996, 1998), also contain embedded questions. Bošković does show that when this interfering factor in indirect questions is controlled for, true indirect questions in SC also exhibit Superiority effects.

4. See, however, Stjepanović (1999) who provides evidence for the existence of phrases between AgrOP and T in SC, and argues that one of these phrases is reserved for hosting the discourse related elements. Furthermore, Stjepanović (1999) shows that what traditionally are called VP adverbs could adjoin as high as this phrase, but crucially the highest position they can be found in is lower than the position in which sentential adverbs are found. See also Boeckx and Stjepanović (2000) who argue for the existence of such a phrase.

5. Although better than (19b), (19a) and (19c) are somewhat degraded on the sentential adverb reading. This is due to the general incompatibility of sentential adverbs in questions. Who wisely advises whom is also somewhat degraded on the sentential reading of wisely.

6. One might suggest at this point that the order of Wh-phrases in (22b)-(24b) is unacceptable because it does not follow the order of the indefinites in the antecedent sentence. However, this is not the case, as illustrated in (i) for (22a):

(i) A: Nekad je neko ovdje sakrio blago.

some.time.ago is somebody here hidden treasure

'Somebody hid the treasure here at some point in the past.'

B: ?Ko kad?

who when

'Who (hid the treasure) when?'

B: $\quad$ ?*Kad ko?

We can see that it is still better to have the higher Wh-phrase first in the linear order, although even this response to the antecedent sentence of the speaker A is a bit unusual. The counterparts of (23a) and (24a) behave in the same way as the counterpart of (22a) in (i).

It is worth checking whether the elliptical answers in the gapping pattern behave in the same way with respect to ordering.

(ii) Ko je koga udario?

who is whom hit

'Who hit whom?'

(iii) a. Marija Petra.

Marija-NOM Petar-ACC

'Marija Petar.'

b. ?*Petra Marija.

Petar-ACC Marija-NOM

'Marija Petar.' 
While it is true that (iiib) is an unnatural answer to (ii), this fact is not relevant to the examples in (22)-(24), since the non-elliptical source of (iiib) has the same kind of degradation as an answer to (ii), which is not the case with corresponding Wh-constructions (cf. (40)):

\author{
(iv) a. \#Petra je udarila Marija. \\ Petar-ACC is hit Marija-NOM \\ 'Marija hit Petar.' \\ b. $\quad$ \#Petra je Marija udarila.
}

A degraded status of (iiib) and (iv) as responses to (ii) may be due to constraints on the ways in which the information in a response to a question is organized, as discussed by Kuno (1982) and Kuno and Takami (1993).

7. Bošković (1997b, 1998b) offers a slightly different account of these facts. Bošković (1997b, 1998 b) proposes that the strong focus feature resides not in the target of movement, but in the moving elements. See Bošković (1997b, 1998b) for more discussion. 


\section{References}

Bolinger, D. 1978. "Asking more than one thing at a time." In Questions, Hiż, H. (ed), 107150. Dordrecht: Reidel.

Boeckx, C. and Stjepanović, S. 2000. "The Wh-clitic connection." In Formal Approaches to Slavic Linguistics: The Philadelphia Meeting, 1999, T. H. King and I. Sekerina (eds), 22-40. Ann Arbor, Mich.: Michigan Slavic Publications.

Bošković, Ž. 1997a. The Syntax of Non-finite Complementation: An Economy Approach. Cambridge, Mass.: MIT Press.

Bošković, Ž. 1997b. "Fronting Wh-phrases in Serbo-Croatian." In Formal Approaches to Slavic Linguistics: The Indiana Meeting, 1996, M. Lindseth and S. Franks (eds), 86107. Ann Arbor, Mich.: Michigan Slavic publications.

Bošković, Ž. 1997c. "Superiority effects with multiple Wh-fronting in Serbo-Croatian." Lingua 102: 1-20.

Bošković, Ž. 1998a. "Multiple Wh-fronting and economy of derivation.” In Proceedings of the Sixteenth West Coast Conference on Formal Linguistics, E. Curtis, J. Lyle and G. Webster (eds), 49-63. Stanford, Calif.: CSLI.

Bošković, Ž. 1998b. Wh-movement and Wh-phrases in Slavic. Position paper presented at the Comparative Slavic Morphosyntax Workshop, Spencer, Ind. [June 1998]

Bošković, Ž. 1999. "On multiple feature checking: Multiple Wh-fronting and multiple head movement." In Working Minimalism, S. D. Epstein and N. Hornstein (eds), 159-187. Cambridge, Mass.: MIT Press.

Bošković, Ž. 2002. “On multiple Wh-fronting.” Linguistic Inquiry 33: 351-383.

Cheng L. and Demirdache, H. 1990. "Superiority Violations." In MIT Working Papers in Linguistics 13: Papers on Wh-Movement, L. Cheng and H. Demirdache (eds), 27-46. Cambridge, Mass.: MITWPL (Department of Linguistics and Philosophy, MIT).

Chomsky, N. 1995. The Minimalist Program. Cambridge, Mass.: MIT Press.

Chung, S., Ladusaw, L. and McCloskey, J. 1995. "Sluicing and logical form." Natural Language Semantics 3: 1-44.

Göbbel, E. 1998. "Focus movement in Romanian." In Proceedings of the Workshop on Focus. University of Massachusetts Occasional Papers in Linguistics 21, E. Benedicto, M. Romero and S. Tomioka (eds), 83-99. Amherst, Mass.: GLSA (Department of Linguistics, University of Massachusetts).

Horvath, J. 1986. Focus in the Theory of Grammar and the Syntax of Hungarian. Dordrecht: Foris.

Izvorski, R. 1996. "The syntax and semantics of correlative proforms." In Proceedings of NELS 26, K. Kusumoto (ed), 133-147. Amherst, Mass.: GLSA (Department of Linguistics, University of Massachusetts).

Izvorski, R. 1998. "Non-indicative Wh-complements of possessive and existential predicates." In Proceedings of NELS 28, P. N. Tamanji and K. Kusumoto (eds), 159-173. Amherst, Mass.: GLSA (Department of Linguistics, University of Massachusetts).

Jackendoff, R. 1971. "Gapping and related rules.” Linguistic Inquiry 2: 21-36.

Jackendoff, R. 1972. Semantic Interpretation in Generative Grammar. Cambridge, Mass.: MIT Press.

Kidwai, A. 1999. Word order and focus positions in Universal Grammar. Ms., Jawaharlal Nehru University. 
Kim, J.-S. 1998. Syntactic focus movement and ellipsis: A minimalist approach. Doctoral dissertation, University of Connecticut, Storrs.

É. Kiss, K. (ed). 1995. Discourse Configurational Languages. Oxford: Oxford University Press.

É. Kiss, K. 1998. “Identificational focus versus information focus.” Language 74: 245-273.

Kitahara, H. 1997. Elementary Operations and Optimal Derivations. Cambridge, Mass.: MIT Press.

Kuno, S. 1982. "The focus of the question and the focus of the answer." In Papers from the Parasession on Nondeclaratives. 18th Regional Meeting of the Chicago Linguistic Society, R. Schneider, K. Tuite and M. Marks (eds), 134-157. Chicago, Ill.: Chicago Linguistic Society.

Kuno, S. and K. Takami. 1993. Grammar and Discourse Principles: Functional Syntax and GB Theory. Chicago, Ill.: The University of Chicago Press.

Lasnik, H. 1999. "On feature strength: Three minimalist approaches to overt movement." Linguistic Inquiry 30: 197-217.

Lasnik, H. and Saito, M. 1992. Move Alpha. Cambridge, Mass.: MIT Press.

Levin, L. S. 1982. "Sluicing: a lexical interpretation procedure." In The Mental Representation of Grammatical Relations, J. Bresnan (ed), 590-654. Cambridge, Mass.: MIT Press.

Merchant, J. 1999. The syntax of silence: Sluicing, islands and identity in ellipsis. Doctoral dissertation, University of California, Santa Cruz.

Ouhalla, J. 1994. "Focus in Standard Arabic." Linguistics in Potsdam 1, 65-92, Potsdam: Department of Linguistics, University of Potsdam.

Pesetsky, D. 1987. "Wh-in situ, movement and unselective binding." In The Representation of (In)definites, E. Reuland and A. ter Meulen (eds), 98-129. Cambridge, Mass.: MIT Press.

Richards, N. 1997. What moves where when in which language? Doctoral dissertation, Massachusetts Institute of Technology, Cambridge.

Rochemont, M. 1986. Focus in Generative Grammar. Amsterdam: John Benjamins.

Rosen, C. 1976. "Guess What About." In Proceedings of NELS 6, A. Ford, J. Reighard and R. Singh, (eds), 205-211. Montreal: Montreal Working Papers in Linguistics.

Ross, J. R. 1969. "Guess who?" In Papers from the 5th Regional Meeting of the Chicago Linguistic Society, R. Binnick, A. Davison, G. Green and J. Morgan (eds), 252-286. Chicago, Ill.: Chicago Linguistics Society.

Rudin, C. 1988. "On multiple questions and multiple Wh-fronting." Natural Language and Linguistic Theory 6: 455-501.

Szabolcsi, A. 1981. "The Semantics of topic-focus articulation. In Formal Methods in Study of Language, J. Groenendijk, T. Janssen and M. Stokhof (eds), 513-541. Amsterdam: Matematisch Centrum.

Stepanov, A. 1998. "On Wh-fronting in Russian." In Proceedings of NELS 28, P. N. Tamanji and K. Kusumoto (eds), 453-467. Amherst, Mass.: GLSA (Department of Linguistics, University of Massachusetts).

Stjepanović, S. 1998. Short distance movement of Wh-phrases in Serbo-Croatian matrix clauses. Paper presented at the Workshop on Comparative Slavic Morphosyntax, Spencer, Ind. [June 1998]

Stjepanović, S. 1999. What do second position cliticization, scrambling, and multiple Whfronting have in common? Doctoral dissertation, University of Connecticut, Storrs.

Takahashi, D. 1994. "Sluicing in Japanese." Journal of East Asian Linguistics 3: 265-300. 
Tsimpli, I. 1994. "Focusing in Modern Greek." In Discourse Configurational Languages, K. É. Kiss (ed), 176-206. Oxford: Oxford University Press.

Vilkuna, M. 1995. "Discourse configurationality in Finnish." In Discourse Configurational Languages, K. É. Kiss (ed), 244-268. Oxford: Oxford University Press.

Watanabe, A. 1993. Agr-based Case Theory and its interaction with the A'-system. Doctoral dissertation. Massachusetts Institute of Technology, Cambridge. 